\title{
STUDY OF DISPLACEMENTS OF A BRIDGE ABUTMENT USING FEM
}

\author{
MICHAŁ WYMYSŁOWSKI, ZYGMUNT KURAŁOWICZ \\ Gdańsk University of Technology, Faculty of Civil and Environmental Engineering, Gdańsk, Poland, \\ e-mail: zonkis@wp.pl,zkur@pg.gda.pl
}

\begin{abstract}
Steel sheet piles are often used to support excavations for bridge foundations. When they are left in place in the permanent works, they have the potential to increase foundation bearing capacity and reduce displacements; but their presence is not usually taken into account in foundation design. In this article, the results of finite element analysis of a typical abutment foundation, with and without cover of sheet piles, are presented to demonstrate these effects. The structure described is located over the Więceminka river in the town of Kołobrzeg, Poland. It is a single-span road bridge with reinforced concrete slab.
\end{abstract}

Key words: bridge abutment, sheet piling, shallow foundation, displacements of the bridge abutment, deformation of the subsoil, finite element method

\section{INTRODUCTION}

Bridges are among those building structures that are constantly subjected to variable loads (variability in time, variability of the intensity of loads and with changing directions of their action). Diversity and specificity of loads cause that the bridge supports under their influence are subjected to vertical and horizontal movements causing rotations. The kind of substructure situated at the edge of bridge - the abutment, is particularly exposed to such displacements. Due to a significant share of earth pressure it is permanently loaded asymmetrically. Moreover, total loads, including movement of vehicles, may exceed the bearing capacity of the soil lying below the base foundation of the bridge abutment. Ensuring that the stress limits in the subsoil are not exceeded, and providing safe displacements are mostly conditioned by the design of the support dimensions and the type of foundations.

In Poland, foundations of bridge abutments (both shallow and deep foundations), because of geotechnical conditions are quite often performed in excavations with a cover of steel sheet piles (Wymysłowski [10]; Wymysłowski and Kurałowicz [11], [12]). Steel sheet piles immersed in subsoil are intended to:

- For a newly built construction, to protect excavation for the foundation against ground water filtration and inflow of water flowing in the water- course adjacent to the excavation, as well as to protect against undermining the foundations of bridge supports which are situated in riverbeds (Jarominiak [3]),

- For an existing construction, to strengthen the foundation in which the stress limit could be exceeded as a result of loads' growth in the subsoil, and to prevent dislocation of the subsoil; also, as in the case of newly designed objects, to protect the foundation against undermining of the bridge supports which are situated in riverbeds (Malý and Remeš [5]).

Despite the fact that the sheet piles are left around the foundation, they are generally not taken into account in the designing of the foundation and the soil bearing capacity. Thus, their importance in determining real support displacements, and the ground deformations under the foundation, is not fully understood and definitely determined. However, modelling investigations on the pillars of a bridge indicate that a cover made of sheet piles significantly increases the bearing capacity of the ground under the foundation, and limits its settlement (Punrattanasin [7]).

The modelling investigations also show that the bridge piers with their foundations in a cover made of sheet piles are able to provide proper protection against seismic forces, and may reduce the costs of foundations in seismic areas (Higuchi et al. [2]; Nishioka et al. [6]). 
Based on the example of a chosen location of one bridge, this article presents multivariate calculations using the finite element method, and analysis of displacements of the bridge abutment on shallow foundation made without, and with, a cover of sheet piles, and their effect on deformation of the subsoil.

\section{COMPUTER SOFTWARTE SELECTION CRITERIA}

In designing and analysis of the static strength of bridges, including their supports, a designer usually uses computer software which utilizes the finite element method. By using finite element method (FEM), designers are able to investigate the response of bridge foundations that cannot be evaluated using simpler methods. In calculation, software bridge supports are generally a collection of finite elements with "stiffness close to infinity". Adoption of such a model eliminates "unreal" deflections of abutment stems or pillars which often, as "stocky structures", are primarily subjected to displacements and rotations. A much more difficult task, which is a challenge for the authors of computer software used in engineering, as well as for designers of bridges, is "modeling" of the subsoil. The problem is to transfer its physical and mechanical properties into the calculation tool as closely as possible, in order to obtain the results of stresses and displacements, both in the subsoil and in the structure, most similar to reality. In designing of bridges, in the case of analysis of a structure and a subsoil, one cannot limit oneself to only a single numerical model describing the construction (generally homogeneous or quasi-homogeneous material).

\section{DESCRIPTION OF ASSUMPTIONS OF THE CALCULATION METHOD IN GEO 5 COMPUTER PROGRAM}

\author{
3.1. CONSTRUCTION OF \\ THE BRIDGE ABUTMENT, AND SOIL \\ AND WATER CONDITIONS \\ IN THE FOUNDATION AREA
}

A single-span road bridge constructed of reinforced concrete slab has been examined. This structure is located nearby the Więceminka river (Kanał Drzewny - the name of the water channel) which is a lateral tributary of the Parsęta river in the town of Kołobrzeg, Western Pomerania, Poland. The bridge abutment has been designed as a massive solid substructure containing a bearing seat and an endwall. A toe and a heel of the foundation have been constructed as asymmetric plinths (the heel is longer than the toe due to decreasing of earth pressure and moving a resultant force from vertical loads towards a road embankment). Cantilever wing walls have been situated parallel to the road axis.

Below foundation level of the bridge abutment there are mostly organic soils. The subsoil has been formed as alternating layers of silts, clays and peats of variable thickness and often stratified by humus sand items.

Bearing layers of the subsoil in the form of sandy clays with an admixture of sandy gravels are situated at a depth of $16.00 \mathrm{~m}$ below the terrain level. For numerical calculations the subsoil parameters shown in Table 1 have been assumed. The ground water level is at a depth of $3.50 \mathrm{~m}$ below the terrain and it is close to

Table 1. Subsoil parameters taken into account for numerical calculations

\begin{tabular}{|c|c|c|c|c|c|c|c|c|c|}
\hline No. & $\begin{array}{c}\text { Type } \\
\text { of the soil }\end{array}$ & $\begin{array}{l}\text { Thickness } \\
\text { of the soil } \\
\text { layer } \\
\\
h \\
\mathrm{~m}\end{array}$ & $\begin{array}{c}\text { Bulk } \\
\text { density } \\
\text { of the } \\
\text { soil } \\
\gamma \\
\mathrm{kN} / \mathrm{m}^{3}\end{array}$ & $\begin{array}{c}\text { Poisson's } \\
\text { factor }\end{array}$ & $\begin{array}{c}\text { Modulus } \\
\text { of the } \\
\text { elasticity } \\
E \\
\mathrm{MPa}\end{array}$ & $\begin{array}{c}\text { Angle } \\
\text { of the } \\
\text { internal } \\
\text { friction } \\
\varphi_{\text {eff }} \\
\text { deg }\end{array}$ & $\begin{array}{l}\text { Consistency } \\
\text { of the soil }\end{array}$ & $\begin{array}{c}\text { Angle } \\
\text { of the } \\
\text { dilatancy } \\
\begin{array}{c}\psi \\
\text { deg }\end{array}\end{array}$ & $\begin{array}{c}\text { Saturated } \\
\text { specific } \\
\text { weight } \\
\text { of the soil } \\
\gamma_{\text {sat }} \\
\mathrm{kN} / \mathrm{m}^{3}\end{array}$ \\
\hline 1 & Embankment & 7.0 & 19.0 & 0.25 & 165.0 & 36.0 & 0.0 & 6.0 & 20.5 \\
\hline 2 & Medium sand & 1.0 & 18.0 & 0.25 & 117.5 & 34.5 & 0.0 & 4.5 & 19.0 \\
\hline 3 & Clayey silt & 1.0 & 17.5 & 0.32 & 5.0 & 10.0 & 15.0 & 0.0 & 18.0 \\
\hline 4 & Black peat & 2.0 & 11.0 & 0.32 & 0.5 & 10.0 & 10.0 & 0.0 & 12.0 \\
\hline 5 & Humus clay & 3.0 & 18.0 & 0.32 & 15.0 & 14.0 & 20.0 & 0.0 & 18.5 \\
\hline 6 & Dark brown peat & 2.0 & 11.0 & 0.32 & 0.5 & 10.0 & 10.0 & 0.0 & 12.0 \\
\hline 7 & Humus clay & 2.0 & 18.0 & 0.32 & 15.0 & 14.0 & 20.0 & 0.0 & 19.0 \\
\hline 8 & Sandy clay & $<4.0$ & 21.0 & 0.32 & 21.0 & 15.0 & 16.0 & 0.0 & 22.0 \\
\hline
\end{tabular}


the level of free surface of the water table in the Więceminka river (Table 1).

\subsection{ADOPTED MODELS OF THE BRIDGE ABUTMENT AND THE SUBSOIL}

An iterative solution has been used to obtain a limit value in calculation of displacements of the bridge abutment and deformations of the subsoil. For modeling bridge abutment with the subsoil, a finite element method in the condition of plane strain PS has been used (User Guide for GEO5 v16, [9]). Adoption of the finite element method (FEM) has required the use of an incremental form of the equilibrium conditions. The Newton-Raphson method (NRM) has been applied for numerical calculations in the GEO FEM software. For description of the subsoil type under the foundation, a plastic model named Mohr-Coulomb has been adopted, which has been described by the following parameters: modulus of elasticity $E$, Poisson's ratio, angle of internal friction and cohesion. The last two parameters determine conditions of plasticity. Effective angle of internal friction $\varphi_{\text {eff }}$ and effective cohesion $c_{\text {eff }}$ have been applied for description of constitutive equations. Because a defined angle of dilatancy affects the magnitude of the plastic volumetric deformation formed during the plastic shearing, it has been assumed that the angle of dilatancy is constant during the plastic deformation (value of $\psi=0^{\circ}$ corresponds to the deformation by shearing with the permanently constant volume). In the case of non-cohesive soil occurring in the subsoil such as sands and gravels $\psi=\psi_{\text {eff }}-30^{\circ}$ has been adopted for calculations and for cohesive soils, such as clays $\psi=0^{\circ}$ has been assumed.

In the numerical model, triangular finite elements with the maximum edge length of $1.00 \mathrm{~m}$ have been adopted for calculations. Two types of mesh compac- tion: so-called linear along the lines of sheet piles and "point" at the ends and at the beginnings of sheet piles' connections (Fig. 1) have been introduced. Length of the edge in the case of mesh compaction has been $15 \mathrm{~cm}$. As the finite elements for modeling of the bridge abutment in numerical calculations should have "infinite" stiffness, for this reason deformations of the mesh nodes have been assumed as zero value. Only displacements of nodes by vector actions have been left possible, whose values have been calculated based on load cases applied to the analyzed structure. Deformations and stresses inside the abutment body have been omitted in order to simplify the analysis. This was neither necessary nor important due to the type of bridge support as "stocky" (i.e., large dimensions) abutment. For this kind of substructure only displacements and rotations have been possible. Mutual distance between nodes of rigid finite elements has been assumed constant according to Šejnoha et al. [8]. The sheet piles have been described by beam finite elements with three degrees of freedom at each node (according to the Mindlin theory). This means that plane cross-section perpendicular to the axis of beam before deflection remains plane after deformation, but not necessarily normal to the axis of the deflected beam. Internal forces have been calculated in the nodes of beam element, based on external forces acting on the ends of the beam.

\subsection{ANALYZED VARIANTS OF THE POSITION OF THE SHEET PILES AS COVER AROUND FOUNDATION OF THE BRIDGE ABUTMENT}

In calculations and analysis for constant geometric parameters for the bridge abutment and permanent soil and water conditions (Table 1) - of shallow foundation of the bridge abutment, 3 combinations of configurations have been taken into account: foundation

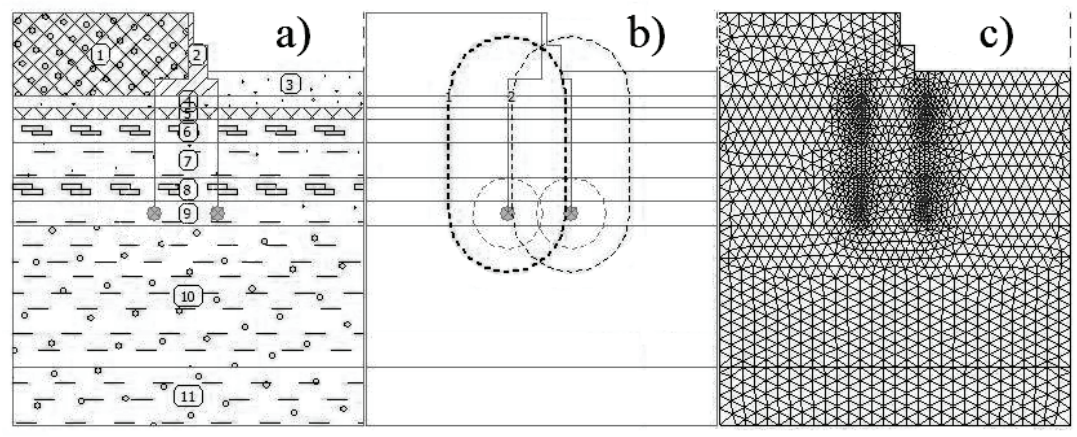

Fig. 1. Data adopted in GEO 5 v16 software: stratification of the subsoil (a), density zones of finite elements (b), mesh of finite elements (c) 
-sheet piling, 4 types (2 horizontal and 2 vertical) of load cases of the bridge abutment, depending on the location of applying the force (through the bearings and on the roadway surface lying on the backfill of road embankment behind the endwall), and 2 directions of loads (vertical and horizontal, Fig. 2). The applied variants of location: foundation-sheet piling:

- option 1: without the cover of sheet piles around the foundation of the bridge abutment (Fig. 2a);

- option 2: with the cover of the G62 sheet piles (length: $10 \mathrm{~m}$ and $16 \mathrm{~m}$ ) around foundation of the bridge abutment (rigid connection to the foundation). Rigid connection of steel sheet piling and foundation of the bridge abutment has been assumed only for calculation. It should have been treated as a theoretical solution, but an adequate approximation of it can be welding reinforcement to the sheet piles and "immersing them" in the concrete of the abutment foundation (Fig. 2b);

- option 3: with the cover of the G62 sheet piles (length: $10 \mathrm{~m}$ and $16 \mathrm{~m}$ ) in close proximity to the foundation. This means that the sheet piles are located $15 \mathrm{~cm}$ away from the peripheral edge of foundation of the bridge abutment (Fig. 2c).

Geometric and material properties of the steel sheet piles G62:

- Young's modulus: $210.0 \mathrm{GPa}$,

- Kirchhoff's modulus: 81.0 GPa,

- cross-sectional area: $78.9 \mathrm{~cm}^{2}$,

- section modulus: $282.0 \mathrm{~cm}^{3}$,

- moment of inertia: $3106.0 \mathrm{~cm}^{4}$.

\subsection{COMBINATIONS OF LOADS ACTING ON THE BRIDGE ABUTMENT, AND THE CALCULATED VALUES OF PHYSICAL PARAMETERS}

In vast numerical calculations and analysis of displacements of the bridge abutment recommendations according to Madaj and Wołowicki [4], relating to the values and directions of loads on the bridge abutments have been taken into account, i.e.:

- self-weight,

- load cases of reaction forces derived from bridge span (from live and dead loads),

- live load cases located directly on the bridge abutment (e.g., loads on cantilevers below pavement plates fixed to wing walls),

- load cases from the ground (from backfill and soil which lies on buried parts of the bridge abutment and from earth pressure),

- dead and live load cases located on backfill of road embankment transmitted onto the bridge abutment via soil (weight of road surface and live loads - only loads located on the active wedge of backfill are taken into account).

Moreover, according to Madaj and Wołowicki [4] in numerical calculations, combinations of load cases acting on the bridge abutment have been taken into account, so as to obtain the maximum limit value of desirable internal forces and their influence on the subsoil, and also the greatest threat to loss of stabil-

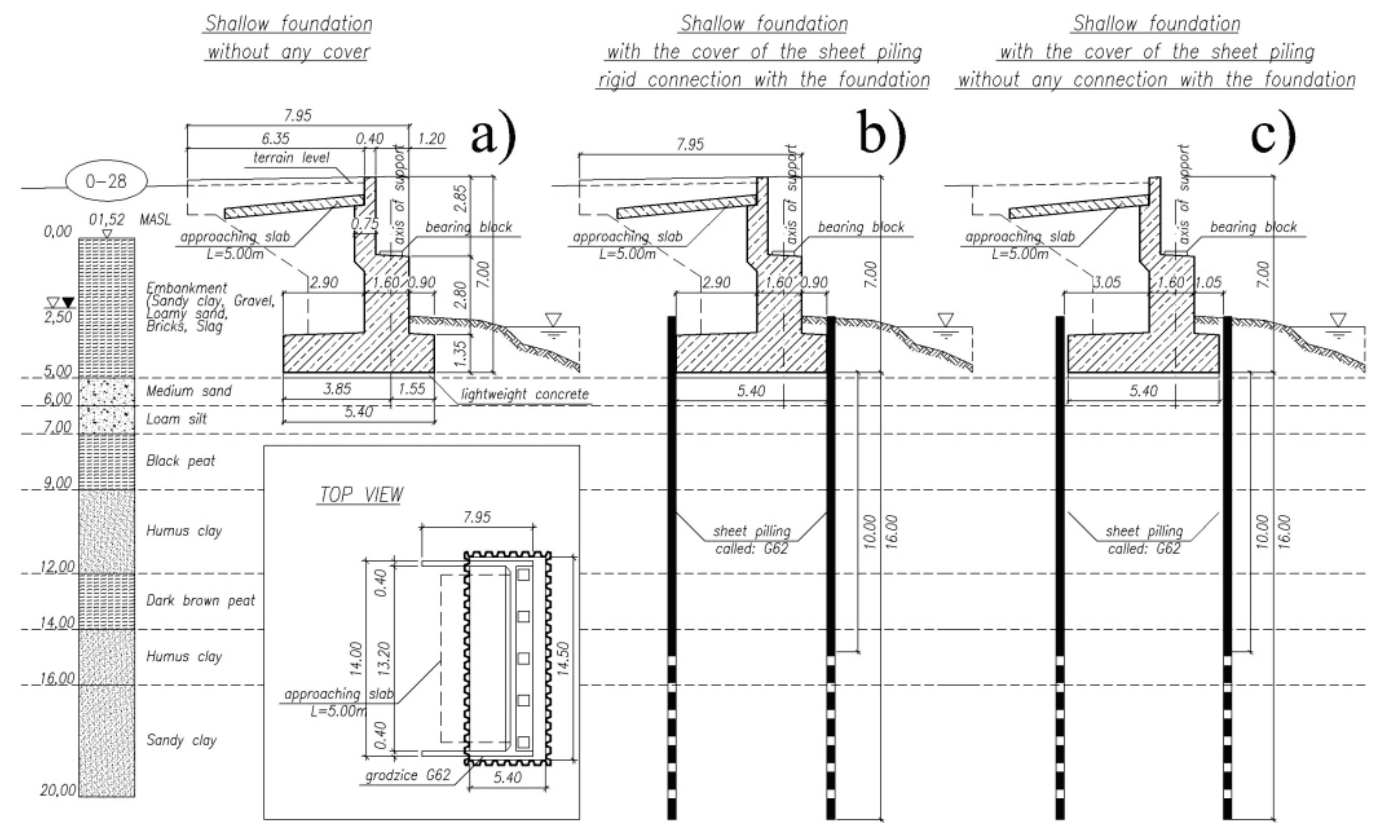

Fig. 2. Diagrams of relation between the foundation of the bridge abutment, and the cover made of sheet piling, adopted in the numerical calculations done by the authors 
ity (sliding and overturning). Forces adopted for designing (a combination of the load cases) have guaranteed capacity conditions for the whole structure and for each of its components, and for the subsoil, and also stability in every phase of construction and operation. In numerical calculations the authors have used the following main combinations of load cases:

- maximum reactions from the load cases on span (maximum reactions from dead and live load cases), lack of loads on the backfill of road embankment,

- minimum reactions from the load cases on span (minimum reactions from dead and live load cases), the most unfavorable load on the active wedge of backfill,

- maximum reactions from the load cases on span (maximum reactions from dead and live load cases), the most unfavorable load on the active wedge of backfill.

Numerical calculations have been divided into two basic groups:

I - the bridge abutment loaded by one type of load case, whose value increased stepwise from 0 to the maximum value (Figs. 4 through 7).

II - the bridge abutment loaded by characteristic combinations of load cases (Fig. 8).

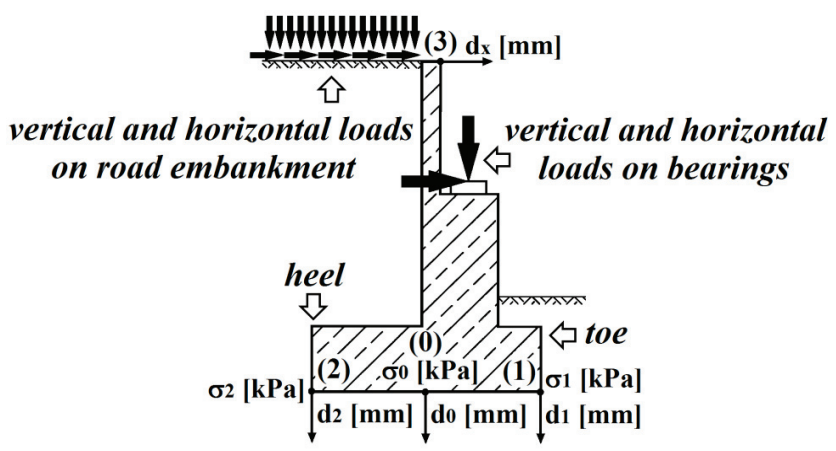

Fig. 3. Location of observed displacements of the bridge abutment, and stresses in the subsoil below the foundation
The following values of physical parameters have been determined based on numerical calculations (Fig. 3):

$\sigma_{1}-$ stress in the subsoil below the front plinth (toe) foundation of the bridge abutment,

$\sigma_{0}-$ stress in the subsoil below the center of the foundation of the bridge abutment,

$\sigma_{2}-$ stress in the subsoil below the rear plinth (heel) foundation of the bridge abutment,

$d_{1}$ - displacement of the abutment foundation at the point of stress $\sigma_{1}$,

$d_{0}$ - displacement of the abutment foundation at the point of stress $\sigma_{0}$,

$d_{2}$ - displacement of the abutment foundation at the point of stress $\sigma_{2}$,

$d_{x}$ - the horizontal displacement of the upper edge of the abutment stem.

\section{RESULTS OF NUMERICAL CALCULATIONS OF DISPLACEMENTS OF THE BRIDGE ABUTMENT}

\author{
4.1. DISPLACEMENTS \\ OF THE BRIDGE ABUTMENT \\ LOADED BY ONE TYPE OF LOAD CASE \\ (VERTICAL/HORIZONTAL) INCREASING \\ INCREMENTALLY AND APPLIED TO THE \\ BEARINGS OR TO THE BACKFILL \\ OF ROAD EMBANKMENT
}

(1) Shallow foundation without any cover around the foundation;

(2) Shallow foundation with the cover of sheet piles G62 $\mathrm{L}=10 \mathrm{~m}$ without connection to the foundation;

(3) Shallow foundation with the cover of sheet piles G62 $\mathrm{L}=16 \mathrm{~m}$ without connection to the foundation;

(4) Shallow foundation with the cover of sheet piles $\mathrm{G} 62 \mathrm{~L}=10 \mathrm{~m}$ rigid connection to the foundation;

(5) Shallow foundation with the cover of sheet piles $\mathrm{G} 62 \mathrm{~L}=16 \mathrm{~m}$ rigid connection to the foundation;

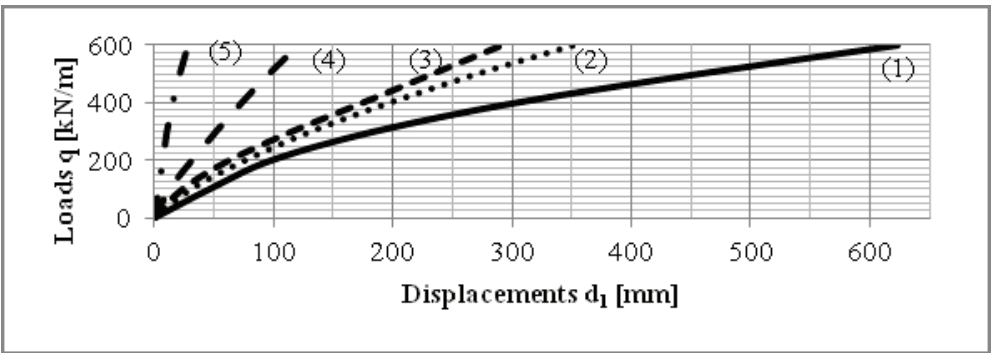

Fig. 4a. Displacements $d_{1}(\mathrm{~mm})$ depending on the use of sheet piles as a cover of the foundation. Vertical load applied at the bearing points 


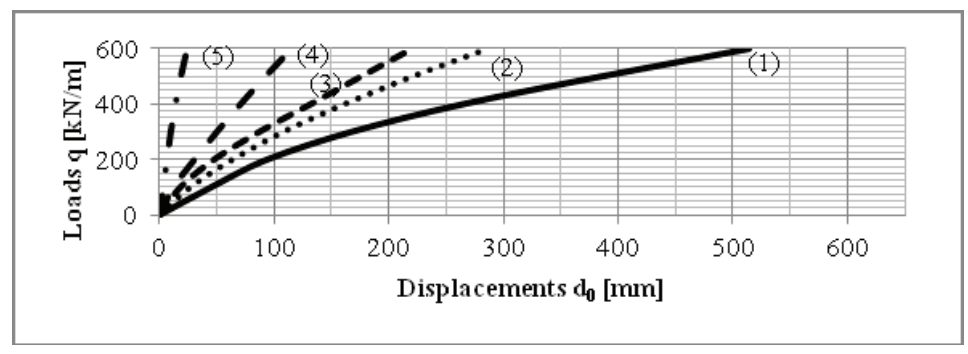

Fig. 4b. Displacements $d_{0}(\mathrm{~mm})$ depending on the use of sheet piles as a cover of the foundation. Vertical load applied at the bearing points

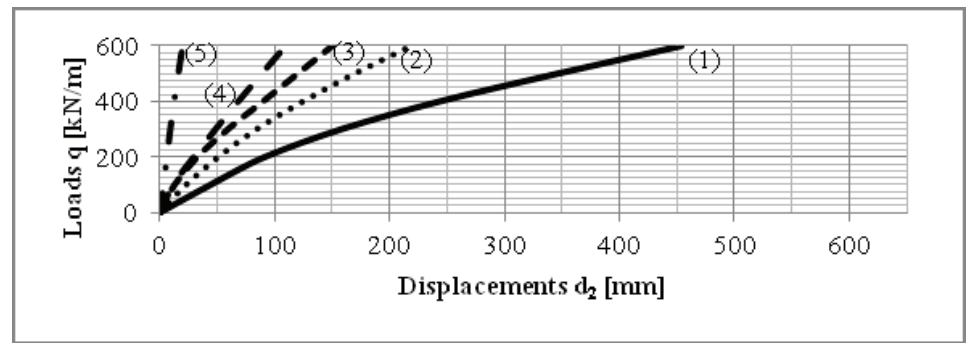

Fig. 4c. Displacements $d_{2}(\mathrm{~mm})$ depending on the use of sheet piles as a cover of the foundation. Vertical load applied at the bearing points

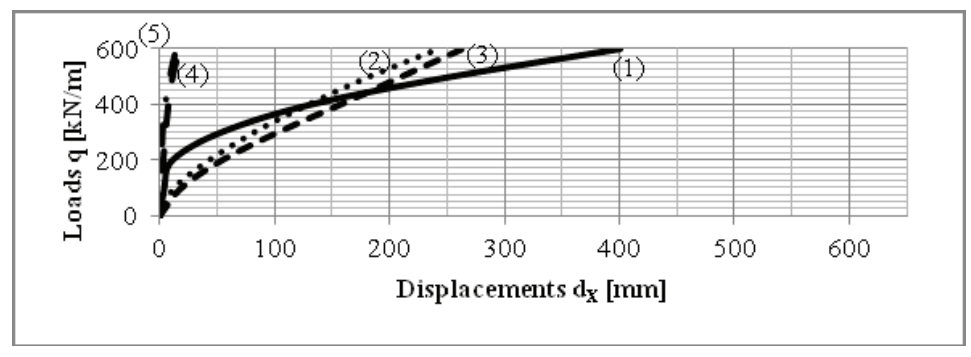

Fig. 4d. Displacements $d_{x}(\mathrm{~mm})$ depending on the use of sheet piles as a cover of the foundation. Vertical load applied at the bearing points

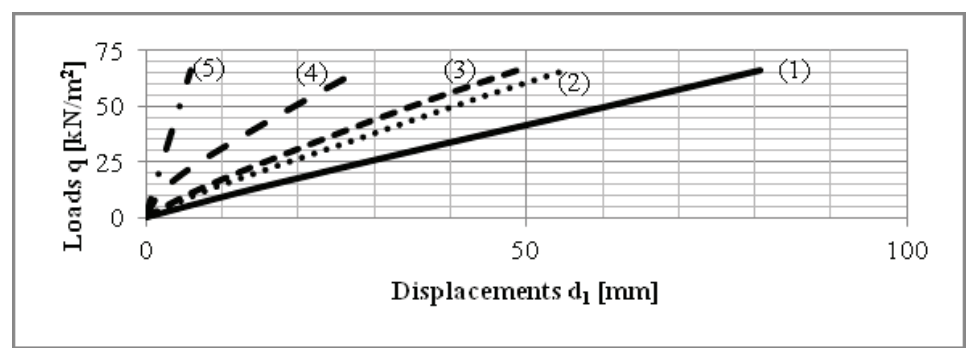

Fig. 5a. Displacements $d_{1}(\mathrm{~mm})$ depending on the use of sheet piles as a cover of the foundation. Vertical load applied on the backfill of road embankment

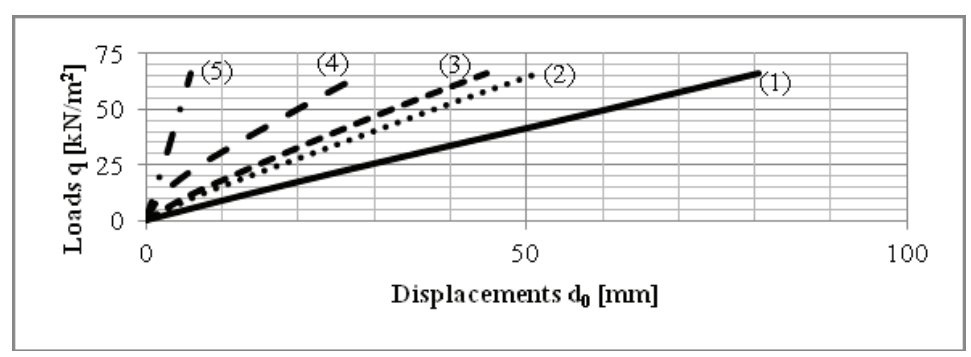

Fig. 5b. Displacements $d_{0}(\mathrm{~mm})$ depending on the use of sheet piles as a cover of the foundation. Vertical load applied on the backfill of road embankment 


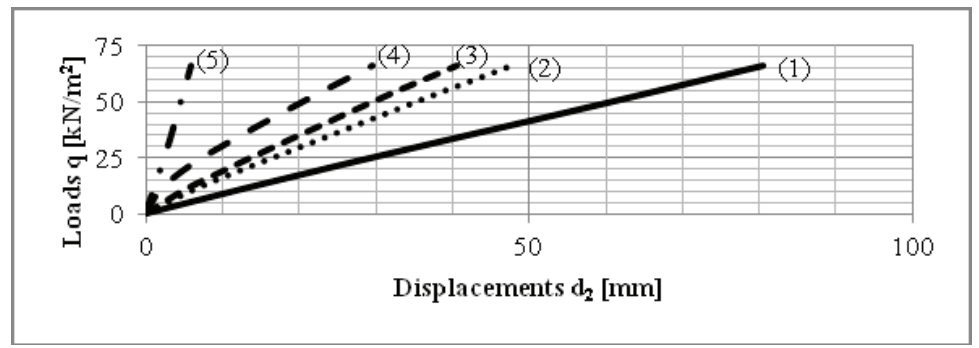

Fig. 5c. Displacements $d_{2}(\mathrm{~mm})$ depending on the use of sheet piles as a cover of the foundation. Vertical load applied on the backfill of road embankment

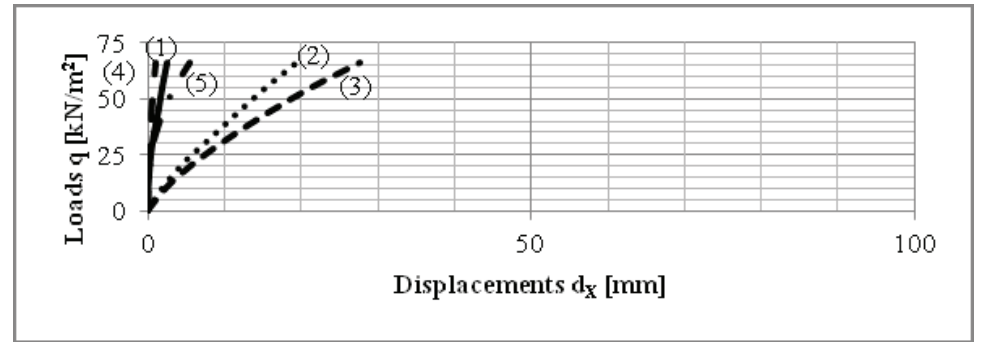

Fig. 5d. Displacements $d_{x}(\mathrm{~mm})$ depending on the use of sheet piles as a cover of the foundation. Vertical load applied on the backfill of road embankment

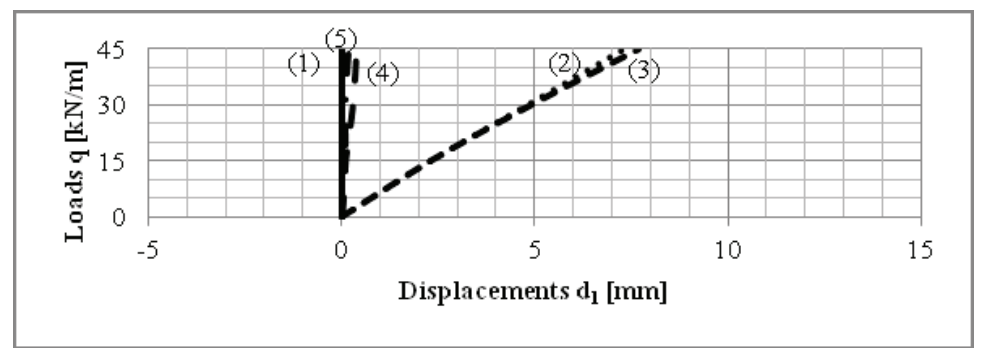

Fig. 6a. Displacements $d_{1}(\mathrm{~mm})$ depending on the use of sheet piles as a cover of the foundation. Horizontal load applied at the bearing points

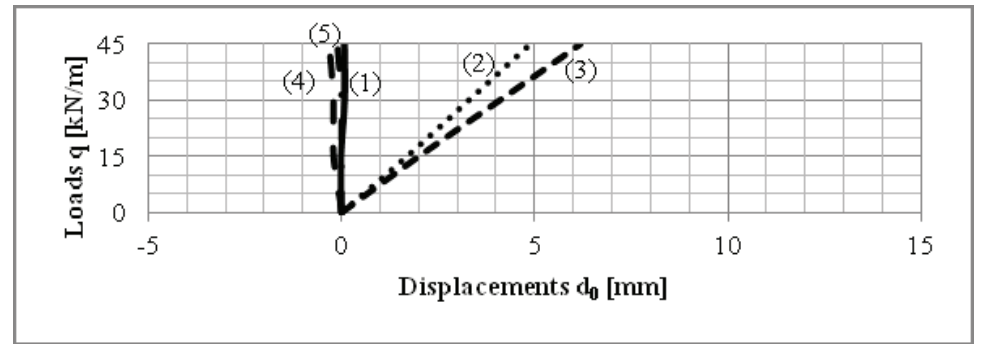

Fig. 6b. Displacements $d_{0}(\mathrm{~mm})$ depending on the use of sheet piles as a cover of the foundation. Horizontal load applied at the bearing points

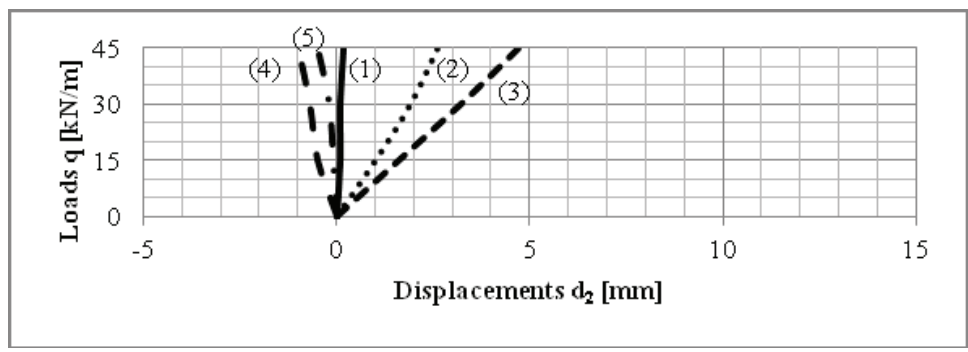

Fig. 6c. Displacements $d_{2}(\mathrm{~mm})$ depending on the use of sheet piles as a cover of the foundation. Horizontal load applied at the bearing points 


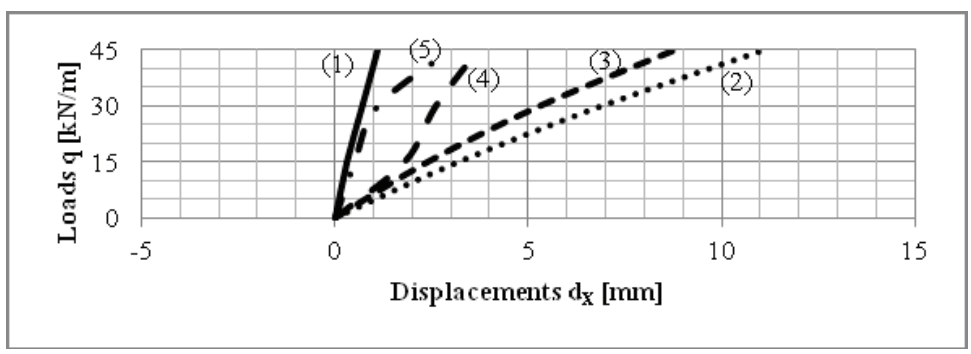

Fig. 6d. Displacements $d_{x}(\mathrm{~mm})$ depending on the use of sheet piles as a cover of the foundation. Horizontal load applied at the bearing points

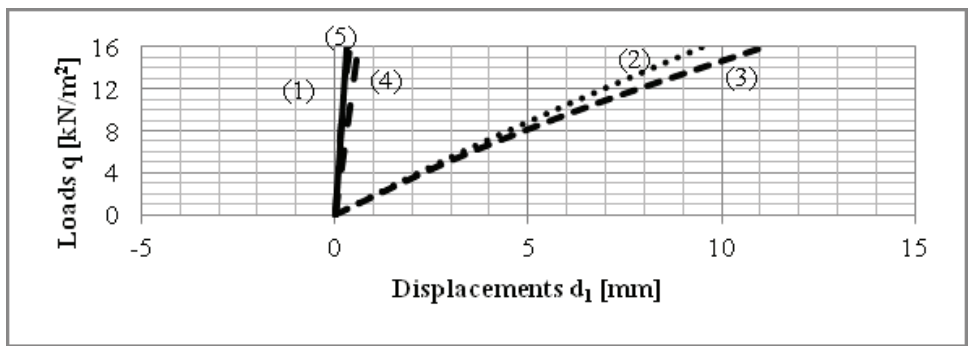

Fig. 7a. Displacements $d_{1}(\mathrm{~mm})$ depending on the use of sheet piles as a cover of the foundation. Horizontal load applied on the backfill of road embankment

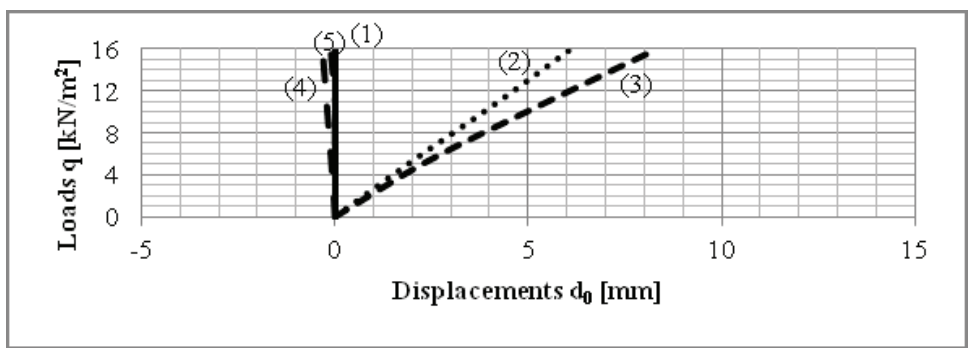

Fig. 7b. Displacements $d_{0}(\mathrm{~mm})$ depending on the use of sheet piles as a cover of the foundation. Horizontal load applied on the backfill of road embankment

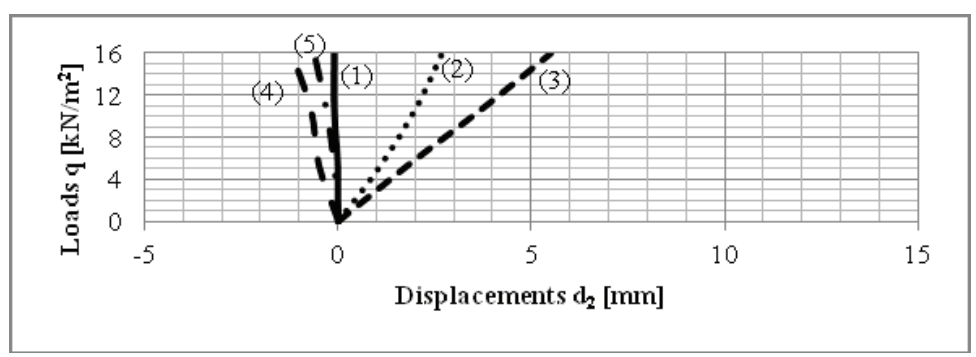

Fig. 7c. Displacements $d_{2}(\mathrm{~mm})$ depending on the use of sheet piles as a cover of the foundation. Horizontal load applied on the backfill of road embankment

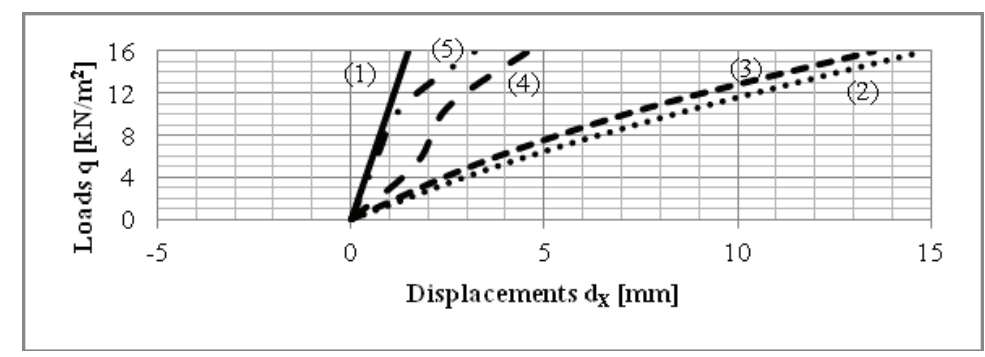

Fig. 7d. Displacements $d_{x}(\mathrm{~mm})$ depending on the use of sheet piles as a cover of the foundation. Horizontal load applied on the backfill of road embankment 


\subsection{COMPARISON OF DISPLACEMENTS OF THE BRIDGE ABUTMENT LOADED BY UNFAVORABLE CHARACTERISTIC COMBINATIONS OF LOAD CASES}

The load cases giving (at the same combination) the most unfavorable results about displacements should be considered from the following list and added, if they are important:

- vertical force (acting on the bearings) caused by self-weight and dead loads and also live loads on bridge span,

- vertical live load acting on road surface and embankment behind the endwall of abutment,

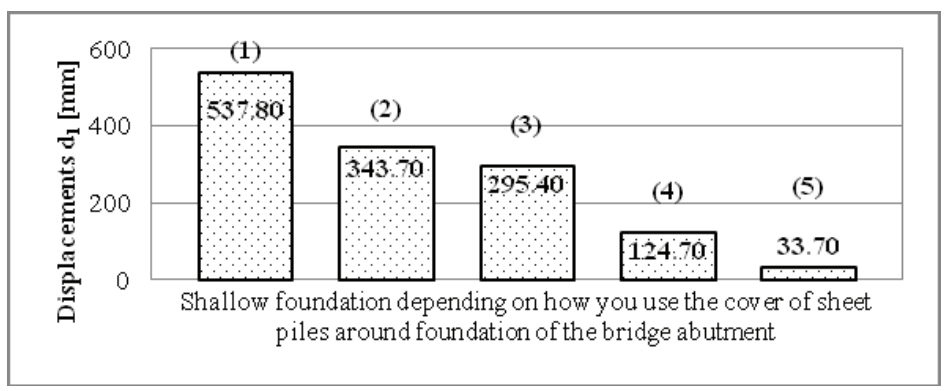

Fig. 8a. Displacements $d_{1}(\mathrm{~mm})$ depending on the use of sheet piles as a cover of the foundation. The most unfavorable combination of load cases

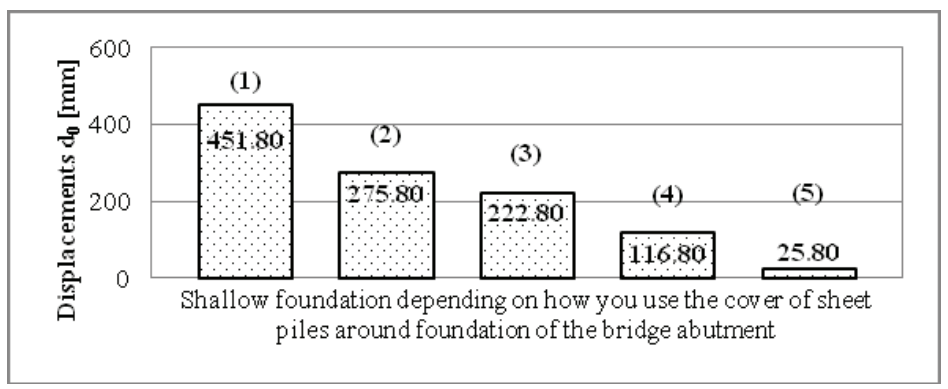

Fig. 8b. Displacements $d_{0}(\mathrm{~mm})$ depending on the use of sheet piles as a cover of the foundation. The most unfavorable combination of load cases

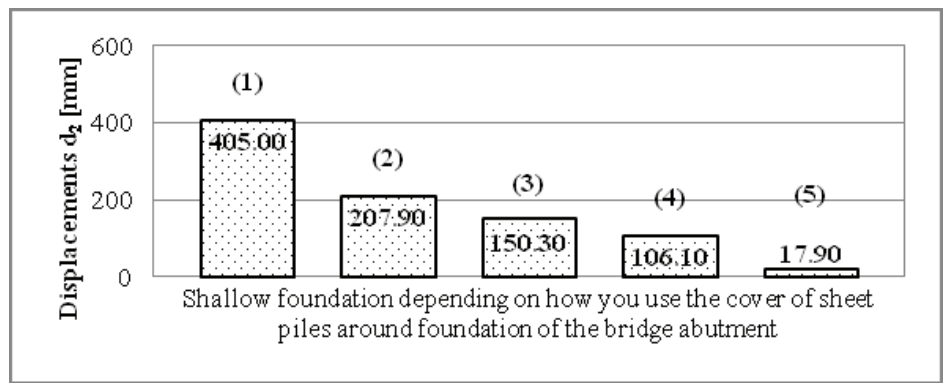

Fig. 8c. Displacements $d_{2}(\mathrm{~mm})$ depending on the use of sheet piles as a cover of the foundation. The most unfavorable combination of load cases

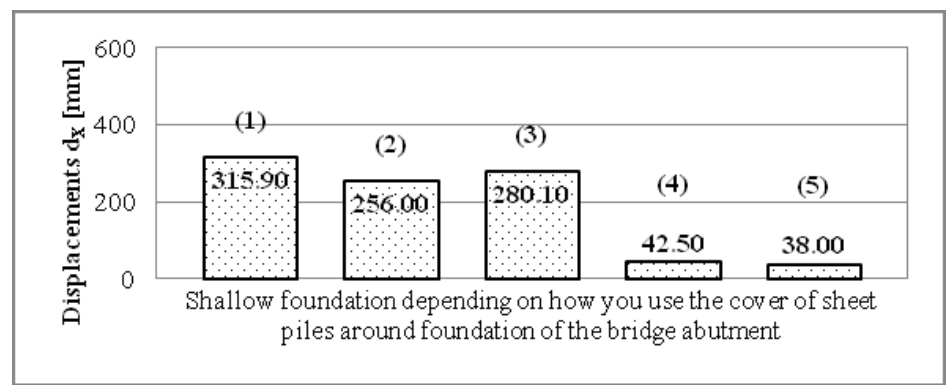

Fig. 8d. Displacements $d_{x}(\mathrm{~mm})$ depending on the use of sheet piles as a cover of the foundation. The most unfavorable combination of load cases 
- braking or accelerating (horizontal force) on bridge span acting on fixed bearings,

- braking or accelerating (horizontal force) on road surface and embankment behind the endwall of abutment,

- earth pressure.

\section{CONCLUSIONS}

Computer calculations of the impact of the presence of a sheet pile casing around foundation directly on the abutment displacement and stress in the subsoil have shown the following:

1. For the same vertical and horizontal abutment load, extending the protective sheet pile foundation will:

- reduce the settlement of the abutment,

- reduce the displacement of the upper edge of the abutment body.

2. Repositioning the sheet pile foundation casing from "no connection to the foundation" to "rigid connection to the foundation" reduces settling and displacement of the abutment.

3. Positioning of the sheet pile as the foundation cover of the abutment subjected to unfavorable combinations of loads, significantly reduced levels of stress in the soil under the foundation. The settlement and displacement of the upper edge of the abutment body are also reduced.

\section{REFERENCES}

[1] GEO5 v16 (GEO FEM) (2013) [computer software]: Fine spol.s r. o.
[2] Higuchi S., Nishioka H., Tanaka K., Koda M., Hirao J., Tsuji N., Tateyama M., Matsuda T., Development of the sheet-pile foundation; A new seismic resistant foundation, The 14-th World Conference on Earthquake Engineering, Beijing, China, October 12-17, 2008.

[3] JarominiaK A., Progress in the foundations of bridges, Geoengineering roads bridges tunnels, 2011, (30)1, 14-33.

[4] Madaj A., Wolowicki W., Podstawy projektowania budowli mostowych, Transport and Communication Publishers, Warsaw 2009.

[5] MALÝ V., REMEŠ M., Structural design for the protection of Pier foundations, 2004/2005, http://www.foundationworld.org.uk/ pdf/charles_bridge_2.pdf.

[6] Nishioka H., Koda M., Hirao J., Higuchi S., Development of Sheet-Pile Foundation that Combines Footing with Sheet Piles, Railway Technical Research Institute, Tokyo, Japan, Quarterly Report, 2008, Vol. 49, No. 2, 73-78.

[7] Punrattanasin P., The Capacity of Sheet Pile Foundation under Eccentric Loading, Proceedings of the Eighteenth International Offshore and Polar Engineering Conference, Vancouver, BC, Canada, July 6-11, 2008, 682-689.

[8] ŠEJnOha M., Zeman J., Janda T., LorenC P., Laurin J., Bureš P., Dlask P., PrušKa J., SMrŽ O., Starŷ J., VANĚČKOVĂ V., (2013).

[9] User Guide for geotechnical software by Fine spol. s r. o. (2013). GEO5 v16 (GEO FEM). Czech Republic.

[10] WyMYSŁOWSKI M., Influence of the cover around foundation on displacement of the bridge abutment, [in:] Archives of Geomatics, Z. Kurałowicz (ed.), The engineering surveys. Measurements and calculations, buildings displacements and surveying services, University of Technology - Faculty of Civil and Environmental Engineering, Gdańsk, Poland, 2013, 51-70.

[11] WymysŁowski M., KuraŁowicz Z., Analysis of displacements of the bridge abutment on the shallow foundation with the cover of sheet piling, Marine and Geotechnical Engineering, 2/2014, 129-139.

[12] WymysŁowski M., KuraŁowicz Z., Displacement of the bridge supports on the foundations covered by sheet piling, [in:] A. Plichta, I. Wyczałek (eds.), The engineering application of geodesy, Poznań University of Technology, Poznań, Poland, 2012, 131-140. 